\title{
OS AND HF ISOTOPE CONSTRAINTS ON THE ORIGINS OF OLIVINE MELILITITES FROM WESTERN SOUTH AFRICA
}

\author{
Philip E. Janney ${ }^{1}$, Anton P. le Roex ${ }^{2}$, Richard W. Carlson ${ }^{3}$ and David R. Bell ${ }^{4}$ \\ ${ }^{1}$ The Field Museum of Natural History, USA; ${ }^{2}$ University of Cape Town, South Africa; ${ }^{3}$ Carnegie Institution \\ of Washington, USA, ${ }^{4}$ Arizona State University, USA
}

\section{INTRODUCTION}

Olivine melilitites are the product of melting carbonated, hydrous, garnet-bearing mantle at fairly great depths (approximately 60-120 km; e.g., Brey, 1978) The petrologic and geochemical similarities between olivine melilitites and Group 1 kimberlites have long been noted (e.g., Boctor and Yoder, 1986), and in many respects olivine melilitites appear to be chemically transitional between Group 1 kimberlites and magmas of the alkali basalt clan (including nephelinites and basanites; e.g., Alibert et al., 1983). In South Africa, the boundary between melilitites and kimberlites, in terms of geographical location and chemical and isotopic composition, is especially gradational.

We have collected $\mathrm{Hf}$ and Os isotope data for a suite of olivine melilitites and related rocks from western South Africa to complement our ongoing major, trace element and $\mathrm{Sr}-\mathrm{Nd}-\mathrm{Pb}$ isotopic studies. Our objectives are to use the $\mathrm{Hf}$ and Os and other isotopic tracers to constrain the mineralogical and chemical composition of the mantle source regions of these rocks and whether they correlate with factors such as lithospheric thickness or age. We further wish to determine to what extent the source compositions and mixing systematics revealed by the melilitites may be analogous to those of southern African Group 1 kimberlites.

\section{SETTING AND AGE CONSTRAINTS}

\section{Geological Setting}

The western margin of South Africa is intersected by two age-progressive alkaline magmatic lineaments of Late Cretaceous-Early Tertiary age (Fig. 1). The first, termed the Western Cape melilitite province is oriented roughly N-S and extends $360 \mathrm{~km}$ from the continental shelf southeast of Cape Agulhas (where alkali basalt and trachytic eruptives occur) to the southern Karoo near the town of Sutherland. This province consists of five main localities, four of which contain true olivine melilitite (Janney et al., 2002 and references therein). This province straddles the boundary between the meso-Proterozoic NamaquaNatal mobile belt to the north and the Pan African age Cape Fold Belt to the south.

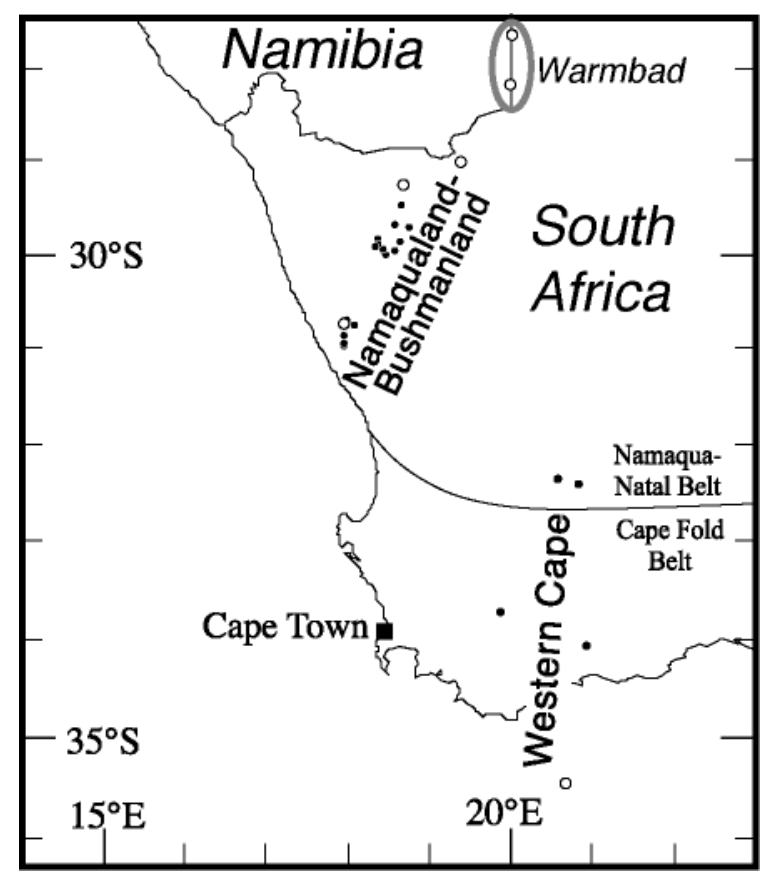

Figure 1: Map of western South Africa and southernmost Namibia showing the location of olivine melilitites (filled) and related rocks (circles) investigated in this study.

The second, termed the NamaqualandBushmanland province (Moore, 1979) is oriented NNESSW and extends over $250 \mathrm{~km}$ from the west coast near the town of Garies onto the Bushmanland plateau south of Pofadder. This province, which lies entirely on Namaqua-Natal mobile belt lithosphere, consists of over 100 pipes. Many of these are sediment-filled or consist of highly altered, diatreme-facies parakimberlite (barren, but yielding picroilmenite, pyrope and zircon in heavy mineral concentrate), but a significant number contain fresh olivine melilitite and accessory nephelinite and carbonatite (Moore and Verwoerd, 1985). The Warmbad kimberlite province, lying northeast of the Namaqualand-Bushmanland melilitites, is a possible extension of this lineament, as 
fresh rock from several pipes in the Warmbad province have strong chemical and mineralogical similarities both to Bushmanland melilitites and Group 1 kimberlites. Although age constraints on these kimberlites are currently lacking, we tentatively group the Namaqualand-Bushmanland and Warmbad provinces into a single magmatic province (abbreviated as the NBW province) based on their spatial relationship and chemical and isotopic similarities.

\section{Age Constraints}

The Western Cape and NBW provinces appear to have been emplaced contemporaneously as age progressive magmatic lineaments. They span age ranges of 58-76 Ma (Dingle and Gentle, 1972; Duncan et al. 1978) and 56-80 Ma (Davis, 1977; Moore and Verwoerd, 1985; G. Kiviets, unpublished data, 2001), respectively, as determined by whole rock and mineral separate $\mathrm{K}-\mathrm{Ar}$ dating, laser fusion ${ }^{40} \mathrm{Ar} /{ }^{39} \mathrm{Ar}$ dating and $\mathrm{U}-\mathrm{Pb}$ zircon geochronology. Ages increase in an approximately linear manner from the coast (or just offshore) to the interior at rates roughly corresponding to those estimated for African plate motion in this time frame (e.g., Hartnady and le Roex, 1985). Although hotspot origins have been proposed for both the Western Cape and NBW provinces (e.g., Duncan et al., 1978) recent plate motion models do not place any currently recognized hotspots within $500 \mathrm{~km}$ of these magmatic provinces in the Late Cretaceous or Early Tertiary.

\section{RESULTS AND DISCUSSION}

\section{Major and trace element chemistry}

Most of the samples studied are near-primary, with $\mathrm{Mg}$ numbers $\left(\mathrm{Mg} \#=100 * \mathrm{Mg} /\left(\mathrm{Mg}+\mathrm{Fe}^{2+}\right)\right)$ between 70 and 80 . Exceptions include submarine alkali basalts from the Alphard Bank (Western Cape) which are moderately fractionated $(\mathrm{Mg} \#=50-55)$ and the southern Garies cluster of olivine melilitites from the NBW province, which are unusually evolved $(\mathrm{Mg \#}$ $=48-68$ ) and may have experienced up to $50 \%$ olivine fractionation. As a result, the Garies cluster melilitites are exceptionally Fe-rich and Si-poor (Moore, 1979).

Alkaline rocks from both the Western Cape and NBW provinces show variations in their relative incompatible abundances that correlate with geographic position. The near-coast localities in both provinces are characterized by incompatible element patterns similar to HIMU-type ocean island basalts (OIB), with positive $\mathrm{Nb}$ and $\mathrm{Zr}$ anomalies and low $\mathrm{Rb} / \mathrm{Nb}, \mathrm{Ba} / \mathrm{Nb}$ and $\mathrm{Th} / \mathrm{Nb}$ ratios. With increasing distance inland, $\mathrm{Nb} / \mathrm{Zr}, \mathrm{Ba} / \mathrm{Nb}$ and $\mathrm{Th} / \mathrm{Nb}$ ratios all increase. In the Western Cape province, enrichments in $\mathrm{Ba}$ and $\mathrm{Th}$ are accompanied by relative depletions in $\mathrm{Zr}$, Hf and $\mathrm{Ti}$ in the localities furthest inland, suggestive of carbonatite metasomatism of their mantle sources (Janney et al., 2002).

\section{$\mathrm{Sr}-\mathrm{Nd}-\mathrm{Pb}$ isotope geochemistry}

Data for the Western Cape and NBW provinces reveals that both display significant $\mathrm{Sr}, \mathrm{Nd}$ and $\mathrm{Pb}$ isotopic heterogeneity $\left({ }^{87} \mathrm{Sr} /{ }^{86} \mathrm{Sr}_{\mathrm{i}}=0.7029\right.$ to 0.7042 ; $\varepsilon_{\mathrm{Nd}(\mathrm{i})}=+4.6$ to $+1.8 ;{ }^{206} \mathrm{~Pb} /{ }^{204} \mathrm{~Pb}_{\mathrm{i}}=17.5$ to 20.5 ; Rogers et al., 1992; Janney et al., 2002 and this study). The near-coastal portions of both provinces contain melilitites and associated rocks that extend to HIMUlike $\mathrm{Sr}-\mathrm{Nd}-\mathrm{Pb}$ isotopic compositions (Fig. 2) and the localities furthest inland in both provinces are characterized by Group 1 kimberlite-like isotopic compositions (e.g., Smith, 1983) with mildly elevated ${ }^{87} \mathrm{Sr} /{ }^{86} \mathrm{Sr}_{\mathrm{i}}$ (0.7035 to 0.7042$)$ and moderate ${ }^{206} \mathrm{~Pb} /{ }^{204} \mathrm{~Pb}_{\mathrm{i}}$ (18.7-19.4). Janney et al. (2002) proposed a model for the Western Cape alkaline province in which the observed isotopic variations were explained as being the result of binary mixing between melts derived from a mafic, sublithospheric HIMU component (expressed most clearly on younger thinner lithosphere near the coast) and melts of metasomatized continental lithosphere having an enriched mantle (EM 1) affinity (expressed most strongly on older, thicker lithosphere inland). However, two facts suggest that the causes of isotopic heterogeneity in these two provinces may be somewhat more complex than indicated by this simple model. First, in the NBW province, the melilitite that most closely approaches the HIMU component is that from Spioenkop, located far inland on the Bushmanland plateau. Second, melilitites from both provinces display an extremely wide variation in $\mathrm{Pb}$ isotope ratios but only a narrow range of unradiogenic $\mathrm{Sr}$ and intermediate $\mathrm{Nd}$ isotope compositions (Fig. 2).

Near-coastal localities from both the Western Cape and NBW provinces include melititites that extend to low ${ }^{206} \mathrm{~Pb} /{ }^{204} \mathrm{~Pb}_{\mathrm{i}}$ ratios (down to 17.5 ). In the case of the NBW province, in which the coastal Garies melilitites are relatively differentiated, these anomalous $\mathrm{Pb}$ isotopic compositions may be plausibly attributed to assimilation of unradiogenic, $\mathrm{Pb}$-rich continental crust during residence in lower crustal magma chambers. However, some near-primary melilitites, including Spiegel River in the Western Cape and Wolfkraal and Bruinkop in Bushmanland (with $\mathrm{Mg} \#>70$ ), also extend to relatively low ${ }^{206} \mathrm{~Pb} /{ }^{204} \mathrm{Pbi}$ values (18.0-19.0), and have low ${ }^{87} \mathrm{Sr} /{ }^{86} \mathrm{Sr}_{\mathrm{i}}$ and moderate $\varepsilon_{\mathrm{Nd}(\mathrm{i})}$ values that place them outside the isotopic fields of kimberlites and most OIB. These 
primitive melilitites do not appear to have undergone significant crustal contamination and thus their low ${ }^{206} \mathrm{~Pb} /{ }^{204} \mathrm{~Pb}_{\mathrm{i}}$ ratios appear to be a feature of their mantle source. One possible explanation for this is that the lithospheric mantle end-member the melilitites sample may be grossly heterogeneous in $\mathrm{Pb}$ concentration and/or in $\mathrm{Pb}$ isotopic composition, resulting in a wide range of hyperbolic mixing curves, as shown on Fig. 2 (Janney et al., 2002). Alternatively, the isotopic heterogeneity displayed by the melilitites may not be the result of mixing isotopically diverse components, but rather could be due to ancient elemental fractionations (caused by the removal or addition of melt generated in the presence of trace phases such as phlogopite or sulfide) within an entirely lithospheric mantle source (Rogers et al., 1992). Both of these hypotheses have difficulty explaining all of the available chemical and isotopic data.

\section{Hf isotopes}

The pioneering study of Nowell et al. (1998) revealed that kimberlites do not describe the same relationship between $\mathrm{Nd}$ and $\mathrm{Hf}$ isotopes as oceanic basalts and most other mantle-derived magmas. In particular, Group 1 kimberlites define a steep array in $\mathrm{Nd}$-Hf isotope with samples falling up to $10 \varepsilon_{\mathrm{Hf}}$ units below mantle array defined by mid-ocean ridge basalts and OIB (Fig. 3). Thus, Group 1 kimberlites appear to sample an endmember with extremely low $\varepsilon_{\mathrm{Hf}(\mathrm{i})}$ and intermediate $\varepsilon_{\mathrm{Nd}(\mathrm{i})}$.

Like southern African kimberlites, the Western Cape alkaline rocks also fall well below the $\mathrm{Nd}-\mathrm{Hf}$ mantle array $(\Delta \varepsilon H f=-4$ to $-8 ; \Delta \varepsilon H f$ is defined as the distance in $\varepsilon_{\mathrm{Hf}}$ units a sample plots above or below the mantle array; see Fig. 3), extending outside the isotopic range of even HIMU-type OIB (Fig. 3) and overlapping with the field for Group 1 kimberlites. However, the limited Hf isotopic variation in these rocks cause them to form a nearly horizontal array in $\mathrm{Nd}-\mathrm{Hf}$ isotope space, which Janney et al. (2002) interpreted as the result of mixing between a HIMU component derived from ancient recycled oceanic crust and a metasomatized continental lithospheric mantle endmember, lying on or near the mantle array at unradiogenic $\varepsilon_{\mathrm{Nd}(\mathrm{i})}$ values. Melilitites from the NBW province also fall well below the mantle array $(\Delta \varepsilon \mathrm{Hf}=$ -6 to -9 ) in a cluster overlapping both the Western Cape field and the Group 1 kimberlite field. As with the Western Cape melilitites, rocks from the NBW province with the strongest HIMU $\mathrm{Sr}-\mathrm{Nd}-\mathrm{Pb}$ isotopic affinities (i.e., from Spioenkop and Dikdoorn) fall furthest below the mantle array and those with more $\mathrm{EM}$-type $\mathrm{Sr}$ and $\mathrm{Pb}$ isotopic characteristics ( i.e, from Border and Hoedkop) fall closest to the mantle array.
This relationship is also indicated by a good correlation between $\Delta \varepsilon$ Hf and ${ }^{87} \mathrm{Sr} /{ }^{86} \mathrm{Sr}_{i}$ and is consistent with the HIMU signature in western South African melilitites being derived from an ancient mafic source material generated in the presence of garnet.

\section{Os isotopes}

Os concentrations and isotope ratios in western South African melilitites span a wide range ([Os] $=399$ to $49 \mathrm{ppt} ;{ }^{187} \mathrm{Os} /{ }^{188} \mathrm{Os}_{\mathrm{i}}=0.133$ to 0.206$)$, with all melilitites measured having supra-chondritic Os isotopic compositions $\left(\gamma_{\mathrm{Os}(\mathrm{i})}=+3\right.$ to +60$)$. As a whole, the melilitites form a relatively well correlated $\left(\mathrm{r}^{2}>\right.$ 0.93 ) array in ${ }^{187} \mathrm{Os} /{ }^{188} \mathrm{Os}_{\mathrm{i}}$ versus reciprocal Os concentration (Fig. 4), the extension of which, at lower Os isotope ratios, passes through the data for southern African Group 1 kimberlites (Pearson et al., 1995). Such an array could be produced by mixing between peridotitic and mafic (pyroxenitic/eclogitic) sources, but could also potentially be produced by an assimilation-fractional crystallization process (Lassiter and Luhr, 2001). Because of the large amounts of crustal assimilation and fractional crystallization required to produce this array, however, we tentatively discount crustal assimilation as a significant cause of Os isotopic heterogeneity in the melilitites.

Although there is some overlap, the NBW province melilitites have, on average, considerably lower ${ }^{187} \mathrm{Os} /{ }^{188} \mathrm{Os}_{\mathrm{i}}$ and higher Os concentrations than those from the Western Cape (Fig. 4). This may be due in part to the fact that several of the Bushmanland melilitites host small peridotite xenoliths (and hence may contain disaggretated Os-rich peridotite fragments), whereas none of the Western Cape melilitites contain mantle xenoliths. The difference may also be a result of variations in lithospheric thickness. All of the NBW melilitites measured are from the Bushmanland plateau, located in the middle of the Namaqua-Natal mobile belt in a region of unusually thick elastic lithosphere (Doucoure et al., 1997). In contrast, the Western Cape province only just penetrates into the southernmost margin of this terrane, where the lithosphere is probably somewhat thinner. A greater contribution from lithospheric mantle might therefore be expected in the NBW melilitites, resulting in lower ${ }^{187} \mathrm{Os} /{ }^{188} \mathrm{Os}$ ratios and higher Os contents.

In the Western Cape province, Os isotope ratios correlate fairly well with $\mathrm{Sr}$ and $\mathrm{Pb}$ isotopes, with the samples having the strongest HIMU affinity also having highly radiogenic Os, and those with the greatest EM-1 lithospheric affinity having the least radiogenic Os. Little such correlation is present in the data from the NBW province. Although samples from Border and Hoedkop, with the strongest EM 1 affinity do have 
among the least radiogenic Os isotope compositions, samples from Spioenkop, which have the strongest HIMU affinity, have nearly identical unradiogenic Os. There is a reasonably good correlation, however, between geographic location and Os isotopic composition, as Os isotope ratios decrease from south to north. Planned Os, Hf and other isotope analyses, including analyses from additional localities, will hopefully more clearly elucidate the relationship between Os isotopes and the other lithophile isotope systems, and the roles of mafic and peridotitic sources in the generation of the NBW province melilitites.

\section{REFERENCES}

Alibert, C., Michard, A. and Albarede, F. 1983. The transition from alkali basalts to kimberlites: isotope and trace element evidence from melilitites. Contrib. Mineral. Petrol. 82, 176-186.

Boctor, N.Z. and Yoder, H.S. 1986. Petrology of some melilite-bearing rocks from Cape Province, Republic of South Africa: relationship to kimberlites. Am. J. Sci. 286, 513-539.

Brey, G. 1978. Origin of olivine melilitites-chemical and experimental constraints. J. Volc. Geotherm. Res. 3, 61-88.

Dingle, R.V. and Gentle, R.I. 1972. Early Tertiary volcanic rocks on the Agulhas Bank, South African continental Shelf. Geol. Mag. 109, 137-146.

Doucour, M., De Wit, M.J. and Mushayandebvu, M.F. 1996. Effective elastic thickness of the continental lithosphere in South Africa. J. Geophys. Res. 101, 11,291-11,304.

Duncan, R.A., Hargraves, R.B. and Brey, G.P. 1978. Age, paleomagnetism and chemistry of melilite basalts in the Southern Cape, South Africa. Geol. Mag. 115.

Hartnady, C.J.H. and le Roex, A.P. 1985. Southern Ocean hotspot tracks and the Cenozoic absolute motion of the African, Antarctic, and South American plates. Earth Planet. Sci. Lett. 75, 245-257.

Hawkesworth, C.J., Erlank, A.J., Kempton, P.D. and Waters, F.G. 1990. Mantle metasomatism: isotope and trace element trends in xenoliths from Kimberley, South Africa. Chem. Geol. 85, 19-34.

Janney, P.E., le Roex, A.P., Carlson, R.W. and Viljoen, K.S. 2002. A chemical and multi-isotope study of the Western Cape olivine melilitite province, South Africa: implications for the sources of Group 1 kimberlites and the origin of the HIMU signature in Africa. J.Petrol. 43, 2339-2370.

Lassiter, J.C. and Luhr, J.F. 2001. Osmium abundance and isotope variations in mafic Mexican volcanic rocks: evidence for crustal contamination and constraints on the geochemical behavior of osmium during partial melting and fractional crystallization. Geochem., Geophys., Geosyst. 2, Paper number GC000116.

Moore, A.E., The geochemistry of the olivine melilitites and related rocks of Namaqualand-Bushmanland, South Africa. PhD, University of Cape Town, 1979.
Moore, A.E. and Verwoerd, W.J. 1985. The olivine melilitite-"kimberlite"-carbonatite suite of Namaqualand and Bushmanland, South Africa. Trans. Geol. Soc. S. Afr. 88, 281-294.

Nowell, G.M., Pearson, D.G., Kempton, P.D., Noble, S.R. and Smith, C.B. 1998. Origins of kimberlites: a Hf isotope perspective. in: Proceedings of the Seventh International Kimberlite Conference, J.J. Gurney, J.L. Gurney and S.H. Richardson, (eds.) The Peter Nixon Volume, Red Roof Design, Cape Town, 1998 pp. 616-624.

Pearson, D.G., Rogers, N.W., Irving, A.J., Smith, C.B. and Hawkesworth, C.J. 1995. Source regions of kimberlites and lamproites: constraints from Re-Os isotopes. Extended abstracts of the Sixth International Kimberlite Conference, 430-431.

Rogers, N.W., Hawkesworth, C.J. and Palacz, Z.A. 1992. Phlogopite in the generation of olivine-melilitites from Namaqualand, South Africa and implications for element fractionation processes in the upper mantle. Lithos 28, 347-365.

Smith, C.B. 1983. Pb, $\mathrm{Sr}$ and $\mathrm{Nd}$ isotopic evidence for sources of southern African Cretaceous kimberlites. Nature 304, 51-54.

Vervoort, J.D., Patchett, P.J., Blichert-Toft, J. and Albar de, F. 1999. Relationships between Lu-Hf and Sm-Nd isotopic systems in the global sedimentary system. Earth Planet. Sci. Lett. 168, 79-99.

Contact: PE Janney, Department of Geology, The Field Museum of Natural History, 1400 S. Lake Shore Dr., Chicago, IL 60605, E-mail: pjanney@fieldmusem.org 


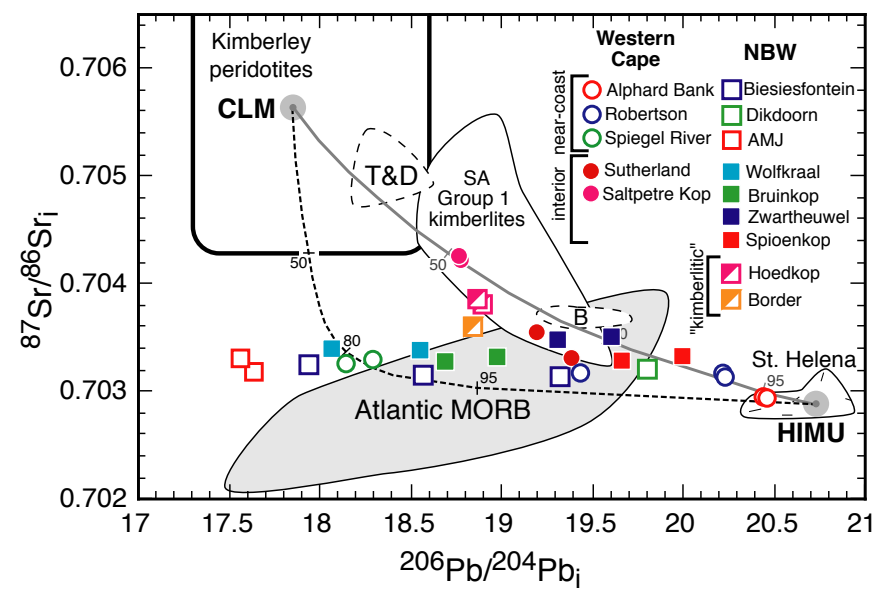

Figure 2. ${ }^{206} \mathrm{~Pb} /{ }^{204} \mathrm{~Pb}_{\mathrm{i}}$ vs. ${ }^{87} \mathrm{Sr} /{ }^{86} \mathrm{Sr}_{\mathrm{i}}$ for the Western Cape and $\mathrm{NBW}$ province melilitites. Melilitite data are from Rogers et al. (1992), Janney et al. (2002) and this study. Kimberlite data are primarily from Smith (1983), peridotite data are initial ranges from Hawkesworth et al. (1990). Fields labelled "T\&D" and "B" are for Tristan Is. and Discovery Smt, and Bouvet Is. respectively. See Janney et al. (2002) for a full list of data references and an explanation of mixing models.

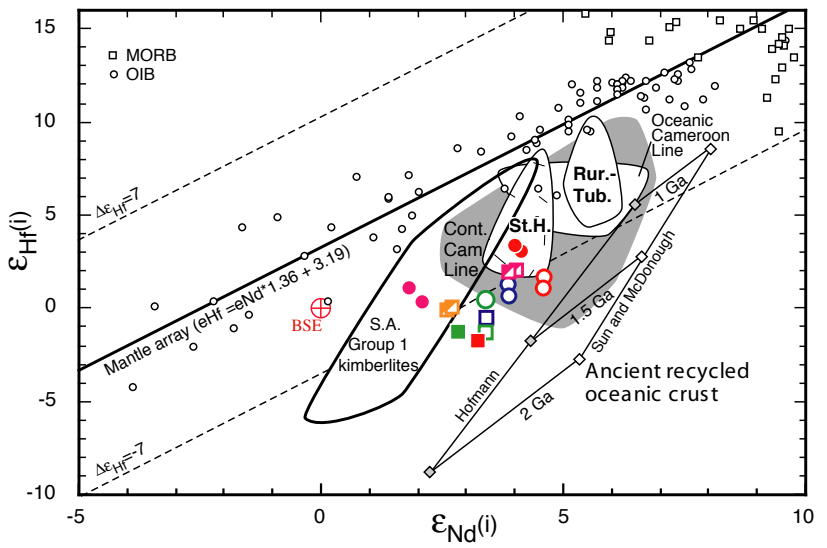

Figure 3. $\varepsilon_{\mathrm{Nd}(\mathrm{i})}$ vs. $\varepsilon_{\mathrm{Hf(i)}}$ for the Western Cape and NBW province melilitites, OIB and MORB. Symbols are the same as in Fig. 2. Melilitite data are from Janney et al. (2002) and this study. Group 1 kimberlite data are from Nowell et al. (1998) and equation for the oceanic basalt "mantle array" is from Vervoort et al., 1999. Also shown are a grid of recycled oceanic crustal compositions for a range of ages and starting MORB compositions. See Janney et al. (2002) for full details and references

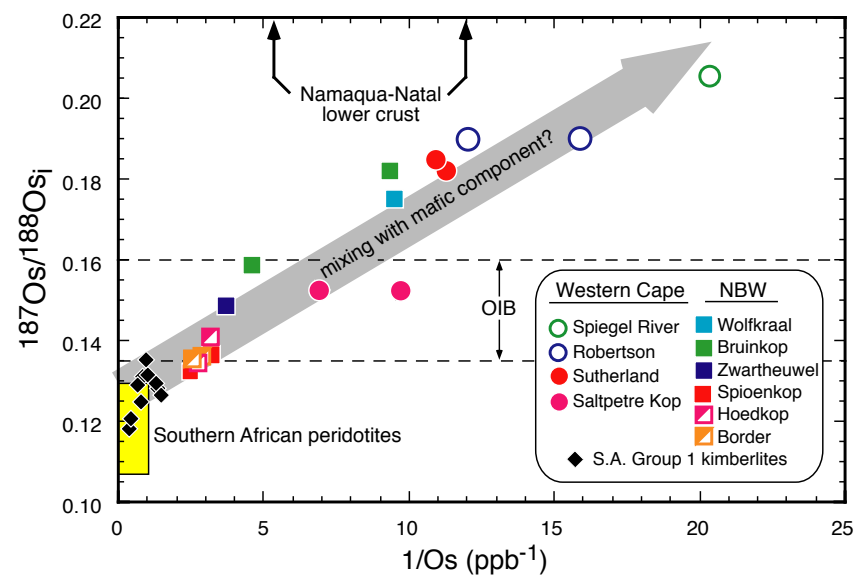

Figure 4. $1 /[\mathrm{Os}]$ vs. ${ }^{187} \mathrm{Os} /{ }^{188} \mathrm{Os}_{\mathrm{i}}$ for the Western Cape and NBW province melilitites. Melilitite data sources are as in Fig. 3. Group 1 kimberlite data are from Pearson et al. (1995), Namaqua-Natal lower crust compositions are from P.E. Janney et al. (unpubl. data, 2000). 